\title{
IMPLEMENTASI READING CULTURE DALAM MENUMBUHKAN MINAT BACA SISWA DI SDIT X DEPOK
}

\author{
Rifina Dwiseptia Hanafi \\ Departemen Ilmu Perpustakaan dan Informasi, Universitas Indonesia \\ email: rifina.dwiseptia@ui.ac.id \\ Kiki Fauziah \\ Departemen Ilmu Perpustakaan dan Informasi, Universitas Indonesia \\ email: kikifauziah@ui.ac.id
}

Received : 18 June 2021

Revised : 29 July 2021

Accepted : 25 September 2021

DOI

\begin{abstract}
This research discusses the implementation of Reading Culture in Developing Student's Reading Interest in SDIT X di Depok. The goal of this research is to identify the implementation of Reading Culture in developing student's reading interest with reading habituation. This research uses qualitative approach with case study method, and held from January 4th to June 14th 2020. The informants of this study were 7 (seven) students of sixth grade, the head of library, and the initiator of Reading Culture. The research of this study aims to show the implementation of Reading Culture in developing student's reading interest. The findings in the implementation of Reading Culture are the rise of new culture and the Mobile Library considered as the most successful program. However, some programs were considered weak because of the hindraces from the students and teachers, the lack of socialization, and incondusive implementation. These implementations are expected to keep evaluated and developed to aims the goals to develops student's reading interest.
\end{abstract}

Keywords: Reading Culture, Literacy program

\section{PENDAHULUAN}

Pada konsep belajar sepanjang hayat (life long learning), membaca adalah salah satu kegiatan yang memiliki peranan penting. Seseorang akan memperoleh pengetahuan dengan membaca. Namun, tanpa adanya minat membaca, manusia tidak akan bisa mengaplikasikan konsep belajar sepanjang hayat di dalam hidupnya. Minat merupakan motivasi yang muncul dari dalam diri seseorang dan sebuah ketertarikan terhadap suatu hal yang dapat berupa benda, aktivitas, atau kegiatan (Legault, 2016; Christina, 2019). Jika dikaitkan dengan membaca, seseorang akan memiliki dorongan dari dirinya sendiri (minat) untuk membaca karena ia menyukainya dan akan mendapatkan kesenangan serta kepuasan ketika membaca. Rahim (2011) mendefisinikan minat baca sebagai perilaku yang 
menunjukkan besarnya keinginan seseorang yang disertai usaha untuk membaca. Namun, minat baca tidak bisa muncul dengan sendirinya karena perlu ditumbuhkan sejak dini agar melekat dalam diri seseorang.

Menurut Wibowo (2015) dalam Kurniasih (2017), pada tahun 2015 Perpustakaan Nasional Republik Indonesia merilis data bahwa hanya $10 \%$ penduduk di atas usia 10 tahun yang memiliki minat terhadap membaca. Setahun kemudian, Indonesia disebut sebagai salah satu negara dengan minat baca rendah dalam sebuah penelitian tahun 2016 yang dilakukan Central Connecticut State University di New Britain, Amerika Serikat, yang berjudul World's Most Literate Nations Ranked. Hasil penelitian itu menempatkan Indonesia di posisi 60 dari 61 negara dan menjadikannya 1 dari 3 negara yang memiliki literasi rendah.

Berkaca pada hasil penelitian tersebut, Indonesia segera berbenah dan dalam sebuah penelitian dua tahun kemudian, yaitu World Reading Habits in 2018 , tentang rata-rata jam yang dihabiskan per orang per minggunya untuk membaca. Indonesia berada di urutan ke-16 dari 30 negara yang terpilih. Penelitian tersebut menunjukkan bahwa orang-orang di Indonesia rata-rata menghabiskan waktu 6 jam per minggunya untuk membaca. Masyarakat Indonesia dinilai memiliki kebiasaan membaca yang cukup tinggi dan dapat berdampak pada minat baca masyarakatnya.

Kebiasaan atau budaya baca merupakan kondisi di mana seseorang memiliki kebiasaan membaca di dalam hidupnya, tetapi bukan untuk kepentingan sekolah (Ailakhu dan Unegbu, 2017). Upaya menumbuhkan minat baca dapat diterapkan sejak sekolah dasar dengan membiasakan anak senang membaca. Seseorang baru dapat dikatakan memiliki kebiasaan membaca jika ia menjadikan kegiatan baca sebagai bagian dari kegiatan sehari-hari dan menjadi kebiasaan yang dibutuhkan serta dinikmati dalam hidupnya (Alex-Nmecha dan Horsfall, 2019). Dalam praktiknya, Perpustakaan Sekolah Dasar Islam Terpadu " $X "$ (selanjutnya akan disebut SDIT X) menerbitkan gagasan untuk membudayakan membaca, yaitu Reading Culture. Salah satu tujuan dari program tersebut adalah untuk menumbuhkan kebiasaan membaca pada siswa-siswi SDIT X. Kebiasaan ini diharapkan akan menumbuhkan minat baca mereka pula.

Sebelum penelitian ini, terdapat penelitian lain tentang minat baca. Penelitian yang berjudul Minat Baca Anak: Studi Kasus Siswa Kelas III di 
Sekolah Citra Alam Jakarta oleh Yasti (2016) mengaitkan aspek-aspek dalam minat membaca pada studi kasusnya. Hasil penelitian menyebutkan bahwa lingkungan dan ketersediaan bahan bacaan merupakan faktor dominan yang memengaruhi minat baca anak, sedangkan aspek tingkat ekonomi tidak berpengaruh terhadap minat baca anak di Sekolah Citra Alam. Berbeda dengan penelitian ini, studi kasus tidak diukur dari aspek-aspek dalam minat baca, tetapi melalui implementasi Reading Culture. Selain itu, studi kasus dilakukan terhadap siswa kelas 6 sebagai partisipan sejak Reading Culture dibentuk.

Dalam penelitian Utami (2015) yang berjudul Reading Challenge sebagai Upaya Peningkatan Minat Baca: Studi Kasus Luckty.wordpress.com dan Renslittlecorner.blogspot.com, disebutkan bahwa reading challenge dapat meningkatkan minat baca, khususnya pada kalangan blogger. Namun, reading challengedi blog hanya dapat meningkatkan minat baca pada orang yang sudah memiliki minat baca. Penelitian tersebutberbeda dengan penelitian ini yang melakukan studi kasus di SD dan menyasar siswa SD. Selain itu, peneliti melihat implementasi gagasan budaya membaca, bukan sekedar tantangan membaca.

Dalam penelitian Pengaruh Membaca 15 Menit terhadap Minat Baca Siswa di Sekolah Dasar oleh Safitri, dkk. (2019), hasilnya diketahui bahwa program membaca 15 menit yang diadakan di sekolahnya memiliki pengaruh terhadap minat membaca siswa (beserta faktor lain yang juga memengaruhi). Dari 42 siswa kelas V SDN 1 Karanglewas Lor terdapat 7 siswa $(16,7 \%)$ yang minat membacanya dalam kategori rendah, 28 siswa $(66,6 \%)$ dalam kategori sedang, dan 7 siswa $(16,7 \%)$ dalam kategori tinggi. Penelitian tersebut dilakukan secara kuantitatif untuk melihat pengaruh program terhadap minat baca siswa. Berbeda dengan penelitian ini yang menggunakan pendekatan kualitatif dan melihat bagaimana implementasi program dalam menumbuhkan minat baca siswa.

\section{METODE PENELITIAN}

Pendekatan penelitian yang digunakan dalam penelitian ini adalah kualitatif yang mengacu pada data teks dan gambar, memiliki tahap analisis data yang unik, serta dapat menggambarkan data pada desain yang berbeda-beda (Creswell, 2014). Metode yang digunakan adalah studi kasus. Menurut Stake (1995) dalam Creswell (2010), studi kasus adalah sebuah strategi penelitian di 
mana peneliti menyelidiki suatu program, aktivitas, proses, atau sekelompok individu secara cermat. Studi kasus dianggap tepat untuk digunakan dalam penelitian ini karena hasil penelitian akan memaparkan hasil dari observasi pada Reading Culture mengenai bagaimana implementasinya dalam menumbuhkan minat baca siswa di SDIT X.

Teknik pemilihan informan pada penelitian ini berupa purposive sampling, yaitu teknik yang menentukan sampel berdasarkan pertimbangan tertentu. Teknik ini merupakan pilihan terbaik untuk membantu peneliti dalam memahami masalah dan pertanyaan penelitian (Creswell, 2014). Melalui teknik ini, peneliti dapat menetapkan pertimbangan dan kriteria tertentu dalam mengambil sampel. Untuk memenuhi kriteria informan kunci yang baik, dibuatlah beberapa kriteria untuk menentukan kelayakan informan:

a. Siswa yang duduk di kelas 6 ,

b. Siswa sudah mengikutiReading Culture sejak pertama kali digagas, dan

c. Siswa peringkat pertama dan/atau terakhir dari masing-masing kelas 6 .

Dalam penelitian ini, peneliti memilih informan dari kelompok siswa untuk unsur pengalaman. Setiap kelas hanya diambil 1-2 orang untuk sampel penelitian. Pengambilan sampel dilakukan agar peneliti mendapat variasi data, tetapi tetap sesuai dengan kriteria kunci.Selain informan kunci, terdapat dua informan pendukung yang akan memberikan informasidari sudut pandang pengelola Reading Culture.

\section{TabelI}

\section{Data Informan}

\begin{tabular}{cccl}
\hline No. & Nama & Usia/Kelas & \multicolumn{1}{c}{ Keterangan } \\
\hline 1. & Lala & 39 tahun & Perempuan. Penggagas Reading Culture. \\
2. & Sinta & 37 tahun & Perempuan. Kepala Perpustakaan. \\
3. & Ara & $6 \mathrm{~A}$ & Perempuan. Perwakilan siswa peringkat rendah. \\
4. & Caca & $6 \mathrm{~A}$ & Perempuan. Perwakilan siswa peringkat tinggi. \\
5. & Hana & $6 \mathrm{~B}$ & Perempuan. Perwakilan siswa peringkat tinggi. \\
6. & Tia & $6 \mathrm{C}$ & Perempuan. Perwakilan siswa peringkat tinggi.
\end{tabular}




$\begin{array}{llll}\text { 7. } & \text { Nana } & \text { 6C } & \text { Perempuan. Perwakilan siswa peringkat rendah. } \\ \text { 8. } & \text { Amina } & \text { 6D } & \text { Perempuan. Perwakilan siswa peringkat tinggi. } \\ \text { 9. } & \text { Brian } & \text { 6D } & \text { Laki-laki. Perwakilan siswa peringkat rendah. }\end{array}$

Teknik yang digunakan dalam pengumpulan data adalah observasi dan wawancara. Observasi dan wawancara dilakukan sejak tanggal 4 Januari 2020 sampai tanggal 14 Juni 2020. Observasi dilakukan oleh peneliti dengan turun langsung ke lapangan untuk mengumpulkan data. Metode wawancara dipilih agar peneliti dapat menggali informasi dari informan secara lebih mendalam dan sesuai fakta di lapangan. Wawancara dilakukan dengan dua cara, yaitu tatap muka dan melalui telepon. Wawancara turut menggunakan ponsel sebagai alat bantu untuk merekam. Data mengenai implementasi Reading Culture didapatkan oleh peneliti melalui wawancara berdasarkan pengalaman informan.

\section{KAJIAN TEORI}

Peneliti mengambil definisi minat baca menurut Rahim (2011) yang menyebutkan bahwa minat baca merupakan perilaku yang menunjukkan besarnya keinginan seseorang yang disertai usaha untuk membaca. Sementara, budaya baca menurut Trudell (2019) adalah perilaku yang dibentuk di sekolah dan perilaku orang dewasa yang bersifat rekreasi. Nyam (2015) dalam Alex-Nmecha dan Horsfall (201)) menyebutkan bahwa budaya baca adalah upaya menjadikan kegiatan sebagai aktivias yang dilakukan secara reguler dan menyenangkan.

\section{HASIL PENELITIAN DAN PEMBAHASAN}

\section{Reading Culture}

Dalam menumbuhkan minat baca siswa, SDIT X mengembangkan sebuah gagasan budaya membaca, yaitu Reading Culture. Gagasan ini dikembangkan pada tahun 2016, kemudian diresmikan dan diimplementasikan di Sekolah Islam Terpadu X di Depok, dari TK hingga SMA, termasuk SDIT X.

Dalam pelaksanaannya, Reading Culture memiliki berbagai program yang dilakukan secara rutin dengan jadwal tertentu dan memiliki acara utama sebagai ajang selebrasi, yaitu Bulan Bahasa. Reading Culture hadir sebagai semangat dan 
upaya untuk menggalakkan kebiasaan membaca sejak dini serta menumbuhkan minat baca siswa di SDIT X. Melalui gagasan ini, siswadiharapkan dapat menjadikan kegiatan baca sebagai bagian dari kegiatan sehari-hari serta kebiasaan yang dibutuhkan dan dinikmati oleh mereka (Alex-Nmecha dan Horsfall, 2019).

\section{Kegiatan Reading Culture dalam Menumbuhkan Minat Baca Siswa}

Dalam upaya menumbuhkan minat baca siswa, Reading Culture memiliki berbagai kegiatan dan Program Budaya Baca yang merupakan implementasi dari rutinitas membaca. Program Budaya Baca terdiri atas beberapa strategi yang berbentuk rangkaian program untuk menumbuhkan budaya membaca pada siswasiswi di SDIT X.

Berikut adalah beberapa program budaya baca dari Reading Culture yang diimplementasikan di SDIT X:

\subsection{Silent Reading}

Silent Reading merupakan kegiatan membaca di dalam hati . Program ini diimplementasikan di setiap kelas dan dilaksanakan secara terjadwal, mulai pukul 7.15 sampai pukul 7.30, tetapi dengan jadwal hari yang berbeda-beda setiap kelasnya. Khusus untuk siswa kelas 1, kegiatan dilakukan setelah melaksanakan ibadah harian, dan dimulai pukul 7.30.

\subsection{OMOB Reading Record}

OMOB (One Month One Book) Reading Record hadir sebagai program yang mendukung kegiatan baca para siswa berupa laporan bacaan. Pada awalnya, Reading Record berupa buku laporan yang diisi oleh wali kelas, tetapi pada tahun 2019 terdapat inovasi pada Reading Record, yaitu perubahan bentuk laporan menjadi online.

Alasan dari perubahan metode Reading Record adalah adanya kendala saat pengisian buku laporan, seperti jadwal pelajaran yang padat, wali kelas tidak memiliki waktu untuk mengisi laporan, dan kesulitan pustakawan dalam melakukan pengawasan program tersebut. Online record hadir sebagai solusi dengan melibatkan siswa untuk berpartisipasi aktif. Siswa akan mencatat judul buku dan halaman terakhir bacaan 
mereka untuk dilaporkan ke website OMOB Reading Record secara mandiri. Laporan itu diisi di rumah dengan dibantu orang tua.

\subsection{Readathon}

Readathon merupakan kegiatan membaca secara serentak. Program ini turut melibatkan guru. Seluruh peserta dikumpulkan di aula atau lapangan sekolah. Pada pelaksanaannya, peserta akan membaca buku yang dibawa secara serentak. Program ini menghadirkan teman membaca untuk siswa (Dowd dan Ochoa, 2011; Trudell, 2019) yang tidak hanya sesama siswa, tetapi juga guru-guru dan kepala sekolah.

"Readathon itu membaca maraton, itu pernah dilakukan di sini. Semester kemarin sih belum. Belum ada lagi nih.” (Ibu Sinta)

\subsection{Kereta Buku Kelas}

Kereta Buku Kelas (selanjutnya akan disebut Kereta Buku) merupakan program yang menyediakan boks kontainer plastik besar berisi berbagai buku koleksi perpustakaan. Kereta Buku berperan penting sebagai penyedia akses buku yang lebih mudah untuk siswa. Program ini merupakan salah satu upaya untuk menumbuhkan budaya membaca dengan menyediakan buku-buku di dalam kelas (Parry, 2000; Trudell, 2019).Setiap kelas akan mendapatkan satu Kereta Buku dan disimpan di masing-masing kelas selama tiga bulan. Isi Kereta Buku akan disesuaikan dengan level kelasnya. Sebagai penanggung jawab Kereta Buku, dua orang siswa akan ditunjuk sebagai petugas perpustakaan kelas.

\subsection{Reading Reward}

Program ini merupakan bentuk apresiasi terhadap siswa-siswi terbaik di rutinitas program budaya baca. Ibu Lala mengatakan setiap bulannya pustakawan akan merekap bacaan siswa dari OMOB Reading Record serta frekuensi peminjaman buku di perpustakaan, kemudian menentukan para The Best Readers yang memiliki minat baca tinggi. 
Pemberian apresiasi dilakukan di depan siswa-siswi lain agar membangunkan antusiasme mereka dalam membaca.

\subsection{Kelas Perpustakaan}

Kelas Perpustakaan merupakan program pendidikan pemakai perpustakaan yang menyasar siswa kelas rendah, yaitu kelas 1-3. Kelas perpustakaan akan dimasukkan ke dalam jadwal pelajaran setiap kelas sehingga wajib untuk dilakukan. Pustakawan akan memberi kompetensi kepustakaan dalam bentuk pembelajaran yang mudah dipahami, seperti sosialisasi aturan pengunjung perpustakaan serta jenis-jenis buku referensi dan koleksi di perpustakaan melalui penayangan video animasi. Untuk beberapa penjelasan kompetensi kepustakaan, siswa-siswi turut dilibatkan dalampraktik langsung agar mereka dapat lebih memahaminya.

\subsection{Perpustakaan Keliling}

Perpustakaan keliling merupakan bagian dari acara Bulan Bahasa. Perpustakaan sekolah bekerja sama dengan Perpustakaan Kota Depok untuk menghadirkan mobil perpustakaan keliling di SDIT X sebagai salah satu rangkaian acara Bulan Bahasa. Perpustakaan Keliling rutin dihadirkan setiap tahunnya saat Bulan Bahasa selama satu hari penuh.

\subsection{Booksharing}

Booksharing adalah berbagi cerita mengenai buku yang telah dibaca oleh siswa saat Silent Reading. Siswa diberi kesempatan untuk menceritakan buku di depan kelas. Kegiatan ini mendukung aktivitas Silent Reading agar siswa tidak hanya membaca buku, tetapi juga berperan aktif untuk berbagi informasi yang ia baca. Christina (2019) menuturkan bahwa kegiatan bercerita dapat menjadi stimulasi untuk menumbuhkan minat anak. Selain itu, kegiatan bercerita juga dapat menjadi variasi untuk membuat anak lebih tertarik dan memiliki minat pada membaca. Hal ini selaras dengan temuan peneliti melalui pengakuan Ara bahwa ia cenderung bosan jika hanya disuruh membaca buku. 


\subsection{Pohon Literasi}

Pohon Literasi merupakan program yang masih berkaitan dengan Silent Reading. Program ini berupa stiker pohon besar yang ditempel di setiap kelas. Siswa akan diminta untuk menulis judul bacaannya di selembar origami berbentuk daun, lalu ditempelkan di Pohon Literasi. Fungsinya sama seperti OMOB Reading Record.

\subsection{Pojok Baca}

Pojok Baca merupakan area yang menyediakan buku bacaan di kelas. Buku-buku yang tersedia dipinjamkanoleh perpustakaan. Siswa juga dapat menaruh buku miliknya agar dapat dibaca oleh siswa lain. Program ini sama seperti Kereta Buku Kelas yang berperan sebagai penyedia akses buku untuk siswa. Kehadirannya turut menumbuhkan minat baca siswa karena menyediakan sumber bacaan di dalam kelas (Parry, 2000; Trudell, 2019) yang dapat diakses dengan mudah.

\subsection{Bulan Bahasa}

Dalam Reading Culture, Bulan Bahasa adalah momen khusus yang dihadirkan sebagai ajang selebrasi bagi warga sekolah setelah mengikutirangkaian program membaca. Kegiatan ini rutin dilaksanakan pada tanggal 28 Oktober setiap tahunnya dengan rangkaian kegiatan yang berjalan selama sepekan. Ibu Lala mengatakan ada acara Bulan Bahasa yang diadakan khusus guru dan dilaksanakan di luar lingkungan sekolah, seperti Depok Town Square dan Perpustakaan Kota Depok. Hal ini dimaksudkan sebagai bentuk syiar ke masyarakat. Pada Bulan Bahasa di Perpustakaan Depok, acara tersebut juga digelar untuk mempromosikan perpustakaan kota kepada masyarakat Kota Depok.

\section{Implementasi Reading Culture}

Pelaksanaan Reading Culture dalam menumbuhkan minat baca siswa tidak seluruhnya sesuai dengan perencanaan. Dari semua program yang dilaksanakan, ada program yang berhasil, program yang lemah, juga terdapat hambatan dalam 
implementasinya. Berikut ini adalah implementasi dari Reading Culture di SDIT $\mathrm{X}$ berdasarkan hasil wawancara dengan informan beserta analisisnya:

\subsection{Hambatan dari Siswa}

Dalam implementasi Reading Culture, ditemukan adanya hambatan dari siswa, yaitu siswa yang tidak membaca, adanya perbedaan antusiasme, dan buku yang kurang diminati. Siswa yang tidak suka membaca ditemukan pada salah satu informan, yaitu Ara.

"Silent Reading saya diem diem bae bu. Saya kan nggak suka baca." (Ara)

Ara mengatakan bahwa saat Silent Reading ia diam saja karena tidak suka baca buku. Namun, ia juga pernah membaca buku dari Kereta Buku Kelas walau hanya dibaca sebentar. Saat Silent Reading, wali kelas kerap mengingatkannya untuk membaca, tetapi ia diam saja. Temuan ini menunjukkan Ara tidak memiliki dorongan dalam membaca buku, baik melalui keinginan dari diri sendiri maupun dari luar.

Hambatan lain dari siswa adalah adanya perbedaan antusiasme. Jika program tidak diikuti secara antusias, tujuan dari program ini akan sulit tercapai. Pada implementasinya, terlihat antusiasme yang berbeda dari setiap informan dalam setiap program dan kegiatan. Saat Silent Reading, antusiasme dapat dilihat dari jumlah siswa yang inisiatif membawa buku dari rumah. Hal ini dilakukan oleh Amina, Tia, Caca, dan Hana yang sudah memiliki kesadaran dari dalam diri mereka untuk membawa buku. Jika tidak membawa, mereka berupaya dengan meminjam buku dari teman. Upaya tersebut menunjukkan minat membaca mereka yang besar karena secara sukarela berusaha mendapatkan bahan bacaan (Rahim, 2011; Herlinyanto, 2015).

Antusiasme siswa juga tampak dari implementasi OMOB Reading Record. Terhadap siswa yang sudah memiliki minat baca seperti Tia, program ini tidak mendorongnya untuk rajin mengisi. Namun, hal itu tidak memengaruhi aktivitas membacanya karena membaca adalah kegiatan yang dia sukai. Sementara itu, temuan dari siswa yang tidak memiliki 
dorongan untuk membaca seperti Ara, imbauan untuk mengisi laporan baca tetap tidak menumbuhkan minat baca sama sekali. Hal ini disebabkan oleh faktor dasar yang belum terpenuhi, yaitu adanya keinginan untuk membaca buku.

Pada pelaksanaan Reading Reward, faktor penentuan The Best Readers dari program ini melihat rekap bacaan dari OMOB Reading Record. Tia mengaku ingin mendapat Reading Reward, sedangkan Ara tidak termotivasi untuk membaca walau ada Reading Reward.

"Aku kompetitif gitu orangnya. Jadi kalau lihat orang yang nilainya bagus itu kayak pengen ngejar, pengen ngelampaui. Tapi kalau the best reader nggak terlalu pengen banget sih. Karena aku emang nggak pernah isi OMOB, jadi pantes aja aku nggak dipanggil jadi the best reader." (Tia)

Tia merupakan siswa yang memiliki minat baca tinggi, tetapi tidak pernah mendapat penghargaan dari Reading Reward. Ia tidak memiliki dorongan untuk mengisi OMOB Reading Record yang menjadi salah satu syaratnya. Sementara itu, Ara mengaku tidak pernah mengisi laporan baca. Ia tidak memiliki semangat untuk membaca agar mendapat reward karena mengaku malas membaca. Berbeda dengan Amina yang merupakan salah satu siswa The Best Reader saat kelas 6. Amina mengutarakan saat itu ia dipanggil ke depan dan mendapat reward berupa alat dan buku tulis, tas, voucher wisata literasi, dan komik islami.

Selain Reading Reward, implementasi lain yang mendapat antusiasme berbeda adalah Pohon Literasi. Pada dasarnya, program ini memiliki fungsi seperti OMOB Reading Record.

"Aku tuh kadang-kadang males nulis, tapi udah peraturan. Tementemen juga kadang males." (Tia)

Tia tidak antusias dengan Pohon Literasi, tetapi tetap berpartisipasi jika diminta oleh guru. Ia mengatakan program ini tidak terlalu diminati oleh siswa, khususnya kelas tinggi. Tia mengungkapkan frekuensi dirinya 
berpartisipasi dalam Pohon Literasi selalu menurun setiap tahunnya. Informan lain mengaku malas untuk menempelkan daun ke Pohon Literasi karena teman-temannya juga jarang menulis. Hal ini menunjukkan jika seorang siswa memiliki antusiasme yang rendah, dapat dipastikan karena lingkungannya juga memiliki antusiasme rendah pula.

"Jarang (nulis) sih soalnya origaminya kadang abislah. Kalau abis yaudah aja gitu. Ada (penanggung jawab) wali kelasnya. Pas kelas 5 sih diomongin, tapi lagi sibuk gurunya." (Hana)

Sementara itu, Hana hanya menulis jika origami berbentuk daunnya masih tersedia. Jika sudah habis, ia memilih untuk tidak menulis. Wali kelas memiliki tanggung jawab untuk menyediakan origami daun, tetapi sering kali daun origami tersebut tidak disediakan kembali.

Dalam meningkatkan minat baca siswa di SDIT X, Reading Culture seharusnya menyediakan sumber bacaan yang sesuai dengan minat siswa. Namun, informan kerap mengeluhkan buku yang tidak sesuai dengan minatnya. Salah satu program yang dikeluhkan karena bukunya adalah Kereta Buku. Menurut wawancara, program ini sebenarnya disukai dan disambut baik oleh siswa, baik yang sudah memiliki fondasi minat pada membaca maupun yang tidak suka membaca. Namun, program ini tidak terimplementasi dengan baik karena variasi buku yang terbatas.

"Bukunya boring. Bukan tipe buku-buku yang aku suka. Biasanya kayak ensiklopedia, sama kayak cerita-cerita rakyat gitu ya. Tapi cerita rakyat itu bukunya udah lumayan kotor... apa ya, halamannya sering hilang gitu." (Amina)

"Bukunya pendek-pendek. Pengennya yang misteri gitu." (Nana)

"Jarang pake sekarang, soalnya udah jarang liat-liat. Bukunya ituitu terus. Bosen. Ya kadang kayak cerita pendek gitu. Sama ada cerita yang tebel, cuma nggak menarik." (Hana) 
"Nggak sering pakai juga sih. Soalnya bukunya tuh buku-buku pendek, tipis. Pinginnya kayak yang tebel kayak yang sastra gitu, hehe. Yang seruuu gitu.” (Qisthy)

"Nggak suka baca buku di kereta (buku) itu. Ada yang menarik, cuma males aja." (Brian)

"Males baca, Bu. Kadang kalau lagi bosen kadang baca sebentar, terus taruh lagi, terus duduk lagi. Diem-diem bae.” (Ara)

"Nggak pake, karena ada buku bawa dari rumah.” (Caca)

Semua informan mengatakan buku-buku di sana cenderung tidak menarik, tipis, dan pendek. Bagi siswa yang sudah memiliki minat baca, seperti Hana, Tia, Caca, dan Amina, Kereta Buku sangat menarik, tetapi variasi bukunya tidak. Oleh karena itu, mereka lebih memilih pinjam buku dari teman atau perpustakaan serta membawa buku dari rumah. Tia juga menyebutkan ada buku yang seharusnya untuk kelas 3, tetapi ada di dalam Kereta Buku kelasnya. Sementara itu, Brian, Ara, dan Nana mengaku sesekali melihat-lihat isi Kereta Buku, tetapi hanya sebentar karena mereka tidak menemukan bacaan yang mereka sukai. Brian dan Ara mengatakan bahwa mereka malas membaca buku. Hal ini membuktikan minat baca mereka tidak tumbuh karena Kereta Buku tidak menyediakan buku yang menarik minat baca siswa.

Hana dan Tia mengakui ada buku di perpustakaan yang menurutnya menarik dan memang disukai oleh siswa, tetapi tidak diadakan di Kereta Buku karena eksemplarnya terbatas. Hal ini selaras dengan pernyataan dari Ibu Sinta, kepala perpustakaan, bahwa buku yang memiliki banyak peminat akan dilayankan di perpustakaan untuk meningkatkan jumlah pengunjung dan dapat diakses oleh lebih banyak orang. Selain itu, jika ditaruh di Kereta Buku, pengawasan pada buku akan menurun dan meningkatkan peluang buku menjadi rusak. Karena bukunya 
cenderung monoton dan membosankan, penggunaan Kereta Buku di kelas tinggi terlihat rendah. Padahal, tinggi-rendahnya minat baca seseorang dilihat dari ketersediaan bahan bacaan (Dalman, 2014). Karena tidak menyediakan kuantitas bacaan yang disukai oleh siswa kelas 6 (Akanda et al., 2013; Noortyani, 2018), Kereta Buku tidak berjalan dengan baik.

Anak akan membaca jika ia menemukan buku dengan topik sesuai minatnya. Jumlah buku yang sedikit dapat menghilangkan kesempatan anak untuk menemukan buku yang ia sukai dan hal itu akan membuat minat baca sulit untuk ditumbuhkan membaca. Minat baca yang rendah memang dapat disebabkan oleh beberapa hal, seperti kurangnya kuantitas bacaan yang disukai oleh seseorang (Akanda et al., 2013; Noortyani, 2018), atau terdapat alasan internal yang membuat seseorang malas membaca (Owusu-Acheaw, 2014; Noortyani, 2018). Salah satu contoh kasus adalah Ara yang memang tidak suka membaca. Namun, ia mengaku pernah tertarik dengan sebuah buku di Perpustakaan Keliling. Hal ini menunjukkan minat membaca dapat tumbuh jika anak menemukan bacaan yang sesuai dengan minatnya.

\subsection{Implementasi Kurang Kondusif dan Tidak Merata}

Dalam menumbuhkan minat baca siswa, program di Reading Culture seharusnya berlangsung dengan kondusif dan merata. Namun, saat Silent Reading berlangsung, beberapa informan mengatakan tidak semua siswa di kelas membaca buku tanpa bersuara. Setidaknya hanya ada setengah siswa di kelas yang berpartisipasi dalam Silent Reading. Tia dan Amina sependapat kelas mereka berisik saat Silent Reading. Ketika peneliti bertanya lebih lanjut, siswa yang tidak membaca biasanya karena tidak membawa buku atau memang tidak ingin membaca. Namun, Caca mengakui Silent Reading di kelasnya berlangsung kondusif. Ia mengatakan semua siswa diam dan tidak berisik sehingga ia bisa membaca dengan tenang. Ia juga menuturkan bahwa semua siswa membaca buku. Namun, ini bertolak belakang dengan pengakuan Ara, teman sekelasnya, yang kerap tidak membaca buku karena tidak suka membaca. 
Jika dilaksanakan dengan baik, Silent Reading dapat menumbuhkan minat baca melalui pembiasaan. Silent Reading 'memaksa' anak untuk membaca buku non pelajaran dengan menyediakan waktu khusus selama 15 menit. Namun, jika anak-anak yang disasar untuk ditumbuhkan minat bacanya tidak melakukan Silent Reading, upaya menumbuhkan minat baca itu tidak akan tercapai. Bahkan, kondisi kelas yang sering kali tidak kondusif akan menghambat pertumbuhan minat baca anak yang benar-benar ingin membaca karena merasa terganggu.

Kondisi yang tidak kondusif juga ditemukan di program lain, yaitu Readathon. Program ini menghadirkan siswa dari level 3-6, guru-guru, hingga kepala sekolah di aula sekolah. Tia mengatakan lokasi pelaksanaan yang terlalu ramai membuat ruangan terasa sesak dan tidak nyaman untuk membaca. Peluang tingginya pertumbuhan minat baca dari kegiatan ini menjadi tidak maksimal karena kondisi yang kurang memadai.

Selain itu, setiap program dan kegiatan Reading Culture tentu sudah direncanakan dan dijadwalkan pelaksanaannya. Namun, ada beberapa implementasi yang dilakukan dengan tidak teratur dan merata. Dalam program Booksharing, guru mempersilakan siswa untuk berpartisipasi secara sukarela. Kegiatan menceritakan buku di depan kelas akan membuat siswa lain mulai mendengarkan dan dapat tertarik dengan buku tersebut (Christina, 2019). Hal ini didukung oleh penuturan Hana bawa ia pernah tertarik untuk membaca buku yang diceritakan temannya. Di luar kegiatan Booksharing, Tia turut mengaku ia pertama kali tertarik membaca buku karangan Tere Liye karena direkomendasikan oleh temannya. Namun, implementasi Booksharing dilakukan dengan tidak teratur. Hal ini dituturkan oleh Amina saat Booksharing di kelas 5.

"Itu pas Silent Reading. Kayak disuruh nyeritain gitu. Eh terus, minggu depannya lagi kan nggak ada Silent Reading, terus minggu depannya lagi yang anak laki nggak jadi tampil.” (Amina)

Pojok Baca merupakan program yang implementasinya belum merata di semua kelas. Informan dari kelas 6A, yaitu Ara, mengatakan 
tidak melihat ada Pojok Baca di kelasnya. Saat peneliti bertanya lebih lanjut tentang rak buku yang ada di kelas, ia hanya menyinggung tentang pojok baca di koridor lantai 1 dan di depan perpustakaan.

"Kalau pojok baca ada di koridor lantai 1 sama di depan perpus, tapi nggak ada di dalam kelas. Kalau di kelas aku pakenya kereta buku. Soalnya di kelas nggak ada rak, seinget aku.” (Ara)

Pengakuan tersebut didukung oleh pernyataan dari Caca, informan dari kelas yang sama. Ia mengatakan tidak ada Pojok Baca di kelasnya. Hal ini menunjukkan bahwa Pojok Baca masih belum diimplementasikan secara merata di semua kelas.

\subsection{Program Minim Sosialisasi dan Berdurasi Pendek}

Dalam menumbuhkan minat baca siswa, Reading Culture seharusnya memiliki sosialisasi program yang baik dan durasi pelaksanaan yang cukup. Dari segi perencanaan, Reading Culture memiliki program yang bagus dan menarik, tetapi hal ini tidak diimbangi dengan sosialisasi yang cukup kepada siswa. Menurut temuan peneliti, tidak semua informan mengetahui OMOB Reading Record dengan baik, khususnya yang daring. Brian, Nana, Ara, dan Tia merupakan informan yang mengetahui laporan bacaan daring. Brian bahkan menyinggung pengisian OMOB secara daring saat peneliti bertanya tentang Silent Reading. Sementara itu, Hana tidak mengetahui jika laporan baca sudah dapat dilakukan melalui internet. Ia mengaku sering membaca, tetapi jarang mengakses OMOB Reading Record. Hal ini menunjukkan sosialisasi inovasi yang tidak tersampaikan dengan baik dapat menyebabkan implementasi yang tidak maksimal. Di sisi lain, Tia yang sudah mengetahui OMOB Reading Record menunjukkan bahwa dirinya tidak tertarik untuk mengisi laporan. Ia mengaku tidak mendapat sosialisasi untuk rajin mengisi OMOB Reading Record sehingga jarang mengisi walaupun sering membaca buku.

Program lain yang kurang disosialisasikan adalah Readathon. Ketika ditanya peneliti, Hana mengaku tidak mengetahui Readathon dan 
merasa tidak pernah melakukan kegiatan tersebut. Hal ini menunjukkan bahwa sosialisasi tidak dilakukan dengan baik sehingga gagal menanamkan kesan pada beberapa siswa.

Selain minim sosialisasi, keluhan lain terkait implementasi Reading Culture adalah durasi yang pendek. Saat Silent Reading, Hana mengaku senang mengikuti kegiatan tersebut, tetapi ia menyayangkan durasi yang singkat. Tia juga mengeluhkan hal serupa. Waktu yang singkat tidak dapat ia manfaatkan secara penuh untuk membaca karena terganggu oleh kelas yang tidak kondusif.

"Kalau Silent Reading tuh cuma dari jam 7 sampai setengah 8, jadi cuma 30 menit doang." (Tia)

Tia mengatakan bahwa Silent Reading berlangsung selama 30 menit. Namun, ia juga mengalami Silent Reading yang singkat karena guru mata pelajaran datang lebih awal. Program lain yang dikeluhkan karena durasi singkat adalah Perpustakaan Keliling. Program ini hanya dihadirkan ke sekolah setahun sekali dan diberlakukan pembagian waktu untuk setiap level kelas, dari level 1 hingga 6. Pembagian waktu ini mendapat keluhan dari siswa, khususnya kelas 6waktu kunjungannya di akhir jam sekolah.

"Perpus keliling itu nanti pergantian level. Pas perpusnya dateng, itu satu level. Abis itu nanti pergantian jam lain jadi level dua, tiga, pokoknya level 6 itu terakhir. Abis itu kami cuma kayak beberapa menit doang. Cuma punya 10-15 menit sih, itu malah sebenernya kurang.” (Tia)

Tia menjelaskan pendeknya durasi juga disebabkan oleh guru mata pelajaran selanjutnya yang datang lebih awal sehingga siswa diminta untuk segera kembali ke kelas. Hal ini cukup disayangkan karena Perpustakaan Keliling mendapatkan antusiasme yang besar dari siswa. Selain itu, program Readathon juga turut dikeluhkan olehnya karena durasi yang singkat untuk membaca. 
Walaupun begitu, ada informan yang mengatakan durasi saat Silent Reading dan Perpustakaan Keliling tergolong cukup lama.

"Biasanya sih (Silent Reading) dari jam 7 sampe jam 8. Agak lama, hehehe." (Caca)

Dalam upaya menumbuhkan minat baca siswa, diperlukan durasi yang cukup untuk membaca agar siswa terbiasa dengan aktivitas tersebut. Siswa yang sudah memiliki minat baca tinggi juga membutuhkan durasi membaca yang lebih banyak. Hal ini seharusnya menjadi perhatian dan evaluasi untuk program yang bersangkutan.

\subsection{Program Paling Berhasil, Paling Lemah, dan Hubungan Antarprogram}

Dari implementasi semua program, peneliti menemukan program yang dinilai paling berhasil dan paling lemah sertahubungan antarprogram yang saling mendukung. Program yang dinilai berhasil dalam menumbuhkan minat baca siswa adalah Perpustakaan Keliling. Caca, Hana, dan Ara mengungkapkan ketertarikannya pada program ini. Lokasi perpustakaan keliling yang berada di luar ruangan memberikan pengalaman baru sehingga membuat mereka tertarik untuk membaca. Selain itu, buku-bukunya jugaberbeda dari koleksi perpustakaan sekolah sehingga menumbuhkan keinginan baca mereka.

Dalam wawancara, Ara merupakan salah satu informan yang mengaku malas membaca, tetapi ia pernah membaca sebuah buku dari perpustakaan keliling yang menarik perhatiannya. Hal ini menunjukkan minat membaca dapat tumbuh jika tersedia koleksi yang sesuai dengan minat seseorang. Tia juga mengakui perpustakaan keliling ini menarik. Kehadiran perpustakaan keliling memang menimbulkan rasa penasaran pada anak karena perpustakaannya berbentuk mobil. Rasa penasaran itu dapat dimanfaatkan untuk membuat anak-anak melihat buku yang tersedia dan membaca buku yang mereka sukai. Beberapa informan juga menyukai perpustakaan keliling karena menyediakan variasi buku yang tidak tersedia 
di perpustakaan sekolah, seperti Nana yang menemukan buku horor di Perpustakaan Keliling. Pengakuan ini membuktikan salah satu indikator yang disebutkan oleh Dalman (2014) bahwa variasi dan ketersediaan bahan bacaan dapat menumbuhkan minat baca seseorang.

Mengenai bahan bacaan yang tersedia di Perpustakaan Keliling, Tia menuturkan bahwa koleksi yang disediakan terpaku dalam stereotip buku anak-anak, yaitu buku yang tipis dan mudah dibaca. Baginya yang kini duduk di kelas 6 dan lebih menyukai novel sastra, Perpustakaan Keliling tidak banyak menyediakan jenis buku yang ia minati. Keterbatasan kuantitas buku dapat membuat keinginan baca anak menyurut dan minat baca anak tidak akan tumbuh. Oleh karena itu, Perpustakaan Keliling harus selalu memperhatikan penggunanya dengan menyediakan buku yang diminati oleh siswa dan tidak terpaku pada stereotip 'anak-anak membaca buku yang mudah dan sederhana'.

Walaupun peneliti menilai program ini cukup berhasil, masih ditemukan beberapa kekurangan, seperti keterbatasan waktu kunjungan. Perpustakaan keliling hanya hadir sekali dalam setahun pada acara Bulan Bahasa. Siswa juga tidak dibebaskan mengakses perpustakaan ini karena diberlakukan giliran untuk setiap level kelas. Tia dan Hana menyayangkan durasi yang singkat untuk menikmati perpustakaan keliling. Mereka mengaku tidak sempat membaca satu bab buku karena pada suatu kunjungan kelasnya hanya mendapat waktu 10 menit.

Selain program paling berhasil, ditemukan juga beberapa program yang dinilai lemah, yaitu Readathon. Implementasinya dilakukan dalam keadaan yang kurang kondusif. Hal ini diutarakan oleh Tia yang mengeluhkan ruangan yang sesak karena ramai dan membuatnya tidak bisa membaca dengan nyaman. Selain itu, Hana mengaku tidak mengetahui program ini. Walaupun ada kemungkinan Hana memberikan tanggapan yang salah karena lupa, hal ini tetap membuktikan bahwa Readathon gagal menanamkan kesan pada siswa. Menurut pengakuan Ibu Sinta, program ini juga belum dilakukan secara rutin.

Kereta Buku merupakan program lain yang dinilai lemah, tetapi berpeluang menjadi program yang berhasil. Buku yang disediakan tidak 
sesuai minat siswa, khususnya kelas tinggi. Selain itu, adanya intervensi dari wali kelas yang berupaya menahan siswa untuk sering membaca buku dari Kereta Buku untuk mengurangi kerusakan dan kehilangan buku. Hal ini cukup disayangkan karena Kereta Buku dapat menjadi program yang berhasil menumbuhkan minat baca siswa jika dilaksanakan dengan tepat.

Peneliti juga menemukan adanya hubungan antarprogram yang mendukung satu sama lain. Program yang paling banyak didukung oleh program lain adalah Silent Reading. Kegiatan Booksharing kerap berhubungan dengan Silent Reading karena dilaksanakan pada jam Silent Reading. Kereta Buku juga mendukung Silent Reading dengan menyediakan buku untuk siswa yang lupa membawa buku. OMOB Reading Record pun merupakan rekap bacaan saat Silent Reading. Sementara itu, Reading Reward berhubungan dengan OMOB Reading Record untuk menentukan siswa yang mendapat gelar The Best Readers.

\subsection{Hambatan dari Guru}

Dalam menumbuhkan minat baca siswa, diperlukan keterlibatan guru dalam implementasi Reading Culture. Namun, peneliti menemukan hambatan yang disebabkan oleh guru. Hana mengatakan ada guru yang membatasi mereka untuk menggunakan buku yang ada di kelas. Ia diingatkan untuk tidak sering-sering membaca dari Kereta Buku. Saat peneliti menyinggung kemudahan mereka dalam mengakses sumber bacaan dengan adanya Kereta Buku, Hana justru menjawab wali kelasnya melarang membaca buku dari Kereta Buku.

"Ya wali kelasnya kemarin ngelarang, nggak ngebolehin baca itu lagi. Kata wali kelasnya soalnya bukunya tuh pada dirusakin gitu lho. Kayak dikasih apa tuh, yang cair itu lho. Apa ya? Correction tape, buat ngehapus pulpen, tapi yang cairnya. Dicoret-coret pake itu." (Hana)

Imbuan guru disebabkan oleh kekhawatiran buku hilang dan rusak. Tindakan ini cukup beralasan karena perpustakaan akan mewajibkan 
penggantian buku. Namun, imbauan tersebutmengurangi potensi Kereta Buku dalam menumbuhkan minat baca siswa.

Hambatan lainnya adalah adanya guru yang tidak optimal dalam menjalankan Silent Reading dan memanfaatkan jam program tersebut untuk kegiatan lain di kelas. Hal ini dituturkan oleh Amina. Saat kelas 6, jika ada siswa yang tidak membaca buku pada jam Silent Reading, wali kelasnya menyuruh siswa yang lupa membawa buku untuk membaca AlQur'an. Padahal Silent Reading dihadirkan untuk memberi waktu untuk membaca selain buku pelajaran. Mata pelajaran Al-Qur'an pun sudah memiliki jadwalnya sendiri. Selain itu,wali kelasnya kerap menggunakan jam Silent Reading untuk ceramah atau menasihati siswa.

"Itu mungkin karena faktor gurunya kali ya, soalnya kan kita masuk jam 7, terus baris, palingan cuma 5-10 menit. Nah, itu biasanya cuma kedapetan baca 10 menit. Bahkan pernah nggak sama sekali baca gara-gara gurunya ceramah.” (Amina)

Berdasarkan penuturan Amina, jika ada siswa yang membuat ulah atau keributan, wali kelas menggunakan jam Silent Reading untuk menasihati siswa di kelas. Hal ini menyebabkan siswa tidak mendapat waktu yang cukup untuk membaca buku pada Silent Reading dan program tidak berjalan dengan optimal.

\subsection{Kultur yang Timbul dari Implementasi}

Pada implementasinya ada sebuah kultur yang timbul, yaitu acara Bulan Bahasa. Acara ini dinilai sebagai kultur karena rutin dilakukan setiap tahun pada tanggal 28 Oktober atau hari Sumpah Pemuda. Selain dirayakan siswa, Bulan Bahasa turut melibatkan seluruh warga sekolah.

\section{PENUTUP \\ Kesimpulan}

Berdasarkan hasil dari penelitian, Reading Culture menghadirkan berbagai program yang menyediakan akses sumber bacaan dan kegiatan untuk 
membudayakan membaca agar dapat menumbuhkan minat baca siswa. Perpustakaan Keliling merupakan program yang dinilai paling berhasil dalam menumbuhkan minat baca, sedangkan Readathon dan Kereta Buku dinilai paling lemah. Selain itu, peneliti menemukan hubungan antarprogram yang mendukung satu sama lain. Namun, dalam implementasinya, terdapat hambatan yang disebabkan oleh siswa, guru, dan implementasi kegiatan itu sendiri.

Peneliti merefleksikan bahwa ada hal yang masih luput dari pelaksanaan program, yaitu prinsip user-oriented. Program yang menarik tidak akan berhasil jika tidak menyesuaikan target dari programnya. Hal ini dapat dilihat dari beberapa implementasi, seperti Kereta Buku. Secara teori, program tersebut dapat menumbuhkan minat baca karena menyediakan akses sumber bacaan. Namun, buku yang disediakan tidak sesuai dengan minat siswa dan guru kerap membatasi siswa untuk menggunakan Kereta Buku. Peneliti berharap implementasi Reading Culture terus dievaluasi dan dikembangkan dengan memperhatikan respons dari siswa agar implementasinya sesuai dan dapat mencapai tujuan untuk menumbuhkan minat mereka.

\section{DAFTAR PUSTAKA}

Aisyah, T. N., dan Kiki Fauziah. (2018). "Strategy to fulfill primary school students' information needs in the digital era." E3S Web of Conferences 74, 08016, ICSoLCA 2018.

Akanda, A.K.M.E.A.,Kazi Mostak Gausul Hoq, dan Nazmul Hasan. (2013). "Reading habit of students in social sciences and arts: A case study of Rajshahi University,"Chinese Librarianship: an International Electronic Journal, 35: 60-71.

Alex-Nmecha, Juliet C, dan Millie N. Horsfall. (2019). "Reading Culture, benefits, and the role of libraries in the 21st century," Library Philosophy and Practice. Juli 2019: 1-11.

Alhamdu, Alhamdu. (2016). "INTEREST AND READING MOTIVATION,"Psikis: Jurnal Psikologi Islami. 1: 1-10. 10.19109/psikis.vli1.552. Diakses pada tanggal 16 Januari 2020.

Brock-Utne, B., dan Hassana Alidou. (2011). "Teaching practices: Teaching in a familiar language," In A. Ouane \& C. Glanz (Eds.), Optimizing learning, education and publishing in Africa: The language factor (pp. 159-186). Hamburg: UNESCO Institute for Lifelong Learning.

Brown, Brendan. (2018). "World Reading Habits in 2018 (Infographic)" Global English Editing. http://eediting.com/world-reading-habits-2018/ Diakses pada 6 Maret 2020.

Christina SP. (2019). Mengajar Membaca Itu Mudah. Yogyakarta: Alaf Media.

Creswell, John W. (2014). Research design: qualitative, quantitative, and mixed methods approaches. California: SAGE Publications, Inc. 
Dalman. (2014). Keterampilan Membaca. Rajawali Pers: Jakarta.

Dowd, A. J., dan Ces Ochoa. (2011). "Literacy boost community action: Creating a culture of reading outside schools walls,"Stockholm: Save the Children. http://resoourcecentre.savethechildren.se/sites/default/fles/documents/6869.pdf.

Faizah, Dewi U., dkk. (2016). Panduan Gerakan Literasi Sekolah di Sekolah Dasar. Jakarta:Direktorat Pembinaan Sekolah Dasar.

Herlinyanto. (2015). Membaca Pemahaman dengan Strategi KWL, Pemahaman dan Minat Membaca. Yogyakarta: Deepublish.

IFLA School Libraries Section Standing Committee. (2015). IFLA School Library Guidelines 2nd revised edition.

Issa, A. O., Mulikat Bola Aliyu, Rachel Bisilola Akangbe, Adegboyega Francis Adedeji. (2012). "Reading interests and habits of the Federal Polytechnic, OFFA, Students,"International Journal of Learning \& Development, 2, (1): 470-486.

Kurniasih, N. (2017). "Reading Habit in Digital Era: Indonesian People do not Like Reading, is it True?" ResearchGate. https://www.researchgate.net/publication/318362570 Diakses pada 13 Februari 2020.

Legault, Lisa. (2016). “Intrinsic and Extrinsic Motivation,"Encyclopedia of Personality and Individual Differences. 10.1007/978-3-319-28099-8_1139-1. Diakses pada tanggal 23 Januari 2020.

Loh, Chin Ee, Mary Ellis, Agnes Paculdar, dan Z.H. Wan (2017). "Building a successful Reading Culture through the school library: A case study of a Singapore secondary school,"IFLA Journal. 43. 034003521773206. 10.1177/0340035217732069. Diakses pada tanggal 16 Januari 2020.

Noortyani, R. (2018). “An Exploratory Study on Students' reading Interest Development through Independent Reading-Retelling Activity,"Arab World English Journal, 9 (2). DOI: https://dx.doi.org/10.24093/awej/vo19no2.7 diakses pada tanggal 7 April 2020.

Owusu-Acheaw, M. (2014). "Reading habits among students and its effect on academic performance: A study of students of Koforidua Polytechnic,"Library Philosophy and Practice (e-journal), 1130, 1-22.

Parry, K. (Ed.). (2000). Language and literacy in Uganda: Towards a sustainable Reading Culture. Kampala: Fountain Publishers Ltd.

Peraturan Pemerintah Republik Indonesia Nomor 24 Tahun 2014 tentang Pelaksanaan Undangundang Nomor 43 Tahun 2007 tentang Perpustakaan.

Rahim, Farida. (2011). Pengajaran Membaca di Sekolah Dasar. Jakarta: Bumi Aksara.

Safitri, L., dkk. (2019). "Pengaruh Membaca 15 Menit terhadap Minat Baca Siswa di Sekolah Dasar”. Jurnal Cakrawala Pendas. Vol. 5 No. 2 Edisi Juli 2019.

Sumanti, D. A., dan Kiki Fauziah (2017). "Implementasi Literasi Informasi dalam Pemenuhan Kebutuhan Informasi Pemustakan di Perpustakaan Kementerian Pendidikan dan 
Kebudayaan,”Jurnal Ilmu Informasi, Perpustakaan, dan Kearsipan - Vol. 19 No. 2, Oktober 2017: 55-62.

Susanto, Ahmad. (2013). Teori Belajar dan Pembelajaran di Sekolah Dasar. Kencana Prenadamedia Group: Jakarta.

Trudell, Barbara. (2019). "Reading in the classroom and society: an examination of "Reading Culture" in African contexts". International Review of Education Vol. 65: 427-442.

Ykema, Sofia. (n.d.). "Increasing Reading Motivation in Young Struggling Readers: Tips for Teachers."

https://www.uwo.ca/fhs/lwm/teaching/dld2_2017_18/Ykema_ReadingMotivation.pdf diakses pada tanggal 16 Januari 2020. 